\title{
19. SEDIMENT PERMEABILITY AT THE NANKAI ACCRETIONARY PRISM, SITE 808 ${ }^{1}$
}

\author{
Elliott Taylor ${ }^{2}$ and Andrew Fisher ${ }^{3}$
}

\begin{abstract}
Coring at ODP Site 808 successfully recovered a sequence of accreted and subducted sediments from the toe of the Nankai convergent margin. Detailed physical properties measurements revealed a systematic downhole consolidation trend, punctuated by two main offsets: a thrust fault at 365 mbsf and a décollement near 950 mbsf. Sediment dewatering during the accretion and subduction processes are strongly influenced by the permeability of the sediments. Results of over 60 permeability measurements made on subsamples of Site 808 cores reveal coefficients of permeability ranging from $10^{-5}$ to $10^{-10} \mathrm{~cm} / \mathrm{s}\left(10^{-14}\right.$ to $\left.10^{-19} \mathrm{~m}^{2}\right)$ in horizontal and vertical directions. The generally low permeability of sediments at the depth of the décollement must influence the stress-strain behavior of this major structural horizon.
\end{abstract}

\section{INTRODUCTION}

Leg 131 of the Ocean Drilling Program successfully penetrated the complete sedimentary sequence of the toe of the Nankai accretionary wedge, through the décollement and subducting sediments, and into the underlying igneous crust (Taira, Hill, Firth, et al., 1991) (Figs. 1 and 2). One goal of this cruise was to characterize the physical, mechanical, and hydrogeologic properties of the products of the early phase of plate convergence. While only one site was cored, one of the most complete suites of measurements from this type of setting was accomplished. This study amplifies that effort, and provides important permeability data required for modeling stress-strain relationships, geochemistry, and heat flow.

Convergent plate boundaries are commonly characterized by the development of a wedge-shaped accretionary complex that is derived from offscraped marine sediments from subducting oceanic plates. One of the most important factors in establishing a "steady state" accretionary wedge is the availability of pore fluids that are supplied through consolidation, low-grade metamorphic dehydration reactions, and thermal expansion at depth. Hubbert and Rubey (1959) and Rubey and Hubbert (1959) were the first to point out the fundamental importance of overpressured pore fluids in the initiation of detachment zones and in the transport of thin thrust slices over long distances. Subsequent models built upon the concept, indicating the role of fluid flow in thrusting (Dahlen et al., 1884; Ngokwey, 1984). Overpressures, in turn, may indicate flow limitations of pore fluid under imposed stress, as overpressured zones required the presence of an aquiclude or aquatard (Gretner, 1976).

The Coulomb wedge analysis of overall shape of accretionary complexes yielded a relation between the pore-pressure ratio and the wedge taper (Davis et al., 1983). Applying such a relationship to many accretionary prisms of known taper suggests that pore fluid pressures are in excess of hydrostatic as a rule (Davis et al., 1983). Shi and Wang (1985) modeled the evolution of pore pressure in an accretionary complex. They found that under a combination of tectonic compression and overburden, high pore pressure can be generated in impermeable sediments when they are brought to a trench by a subducting plate.

\footnotetext{
${ }^{1}$ Hill, I.A., Taira, A., Firth, J.V., et al., 1993. Proc. ODP, Sci. Results, 131: College Station, TX (Ocean Drilling Program).

${ }^{2}$ Woodward-Clyde Consultants, 900 Fourth Avenue, Suite 3440, Seattle, WA 98164 , U.S.A.

${ }^{3}$ Department of Geophysics and Ocean Drilling Program, Texas A\&M University, 1000 Discovery Drive, College Station, TX 77845, U.S.A
}

Sediment deformational behavior is dependent upon stress history, state of stress, and stress-strain properties. Deformation also strongly depends on the permeability of the accretionary/subduction system, through a likely combination of matrix and fracture permeability. One of the most indicative properties for establishing stress history is sediment porosity (Bray and Karig, 1986; Karig, 1986). Porosity is an important index of consolidation, and hence permeability, because it is a function of lithology and loading history. It is expected that marine sediments undergoing accretion ultimately develop significantly lower porosities than those that are consolidated in undisturbed basinal sequences (Carson, 1977; Shephard and Bryant, 1983; Fowler et al., 1985). This observation has not been adequately documented in modern active margin settings. Karig (1985) proposed a rapid porosity decrease with depth and with distance landward from the wedge toe in the frontal parts of an accretionary wedge, leveling off gradually with increasing distance from the deformation front. Davis and von Huene (1987) assumed that the bulk of active compressional deformation is concentrated in the first $5-15 \mathrm{~km}$ of the Barbados, Nankai, and Middle America accretionary prisms. At the Barbados Ridge complex, only moderate dewatering was observed within the toe of the prism (Moore, Mascle, et al., 1988; Taylor and Leonard, 1990).

Realistic modeling of the deformational behavior of accreted sediments is seriously hampered by the lack of good in-situ data. Mechanical modeling (Carson and Berglund, 1986) and hydrological modeling (Shi and Wang, 1985, 1987; Screaton et al., 1990; Wuthrich et al., 1990) require measured boundary conditions of structural, constitutive, stress, and hydrologic conditions of these active margins to refine continued efforts. To quantitatively evaluate sediment consolidation state, in-situ measurements of both pore pressure and stress are needed; however, most studies of pore pressure and in-situ stress, to date, depend on indirect evidence. The existence of abnormal pore pressures in excess of hydrostatic around accretionary wedges has been inferred both from indirect observations and theoretical modeling (von Huene and Lee, 1983). Mud volcanoes and mud diapirs at the Barbados Ridge complex provide evidence of overpressures (Stride et al., 1982; Westbrook and Smith, 1983). Similar evidence has also been observed at the Nankai margin (Taira et al., in press). Overpressures and fluid release which form mud volcanoes provide an indication of the permeability structures of these margins in which low permeability formations may be transected by more permeable conduits. The permeability structure of offscraped and subducted sediments, and the décollement is central to both natural and modeled systems; this paper addresses this aspect of the hydrogeologic regime at the Nankai prism. 


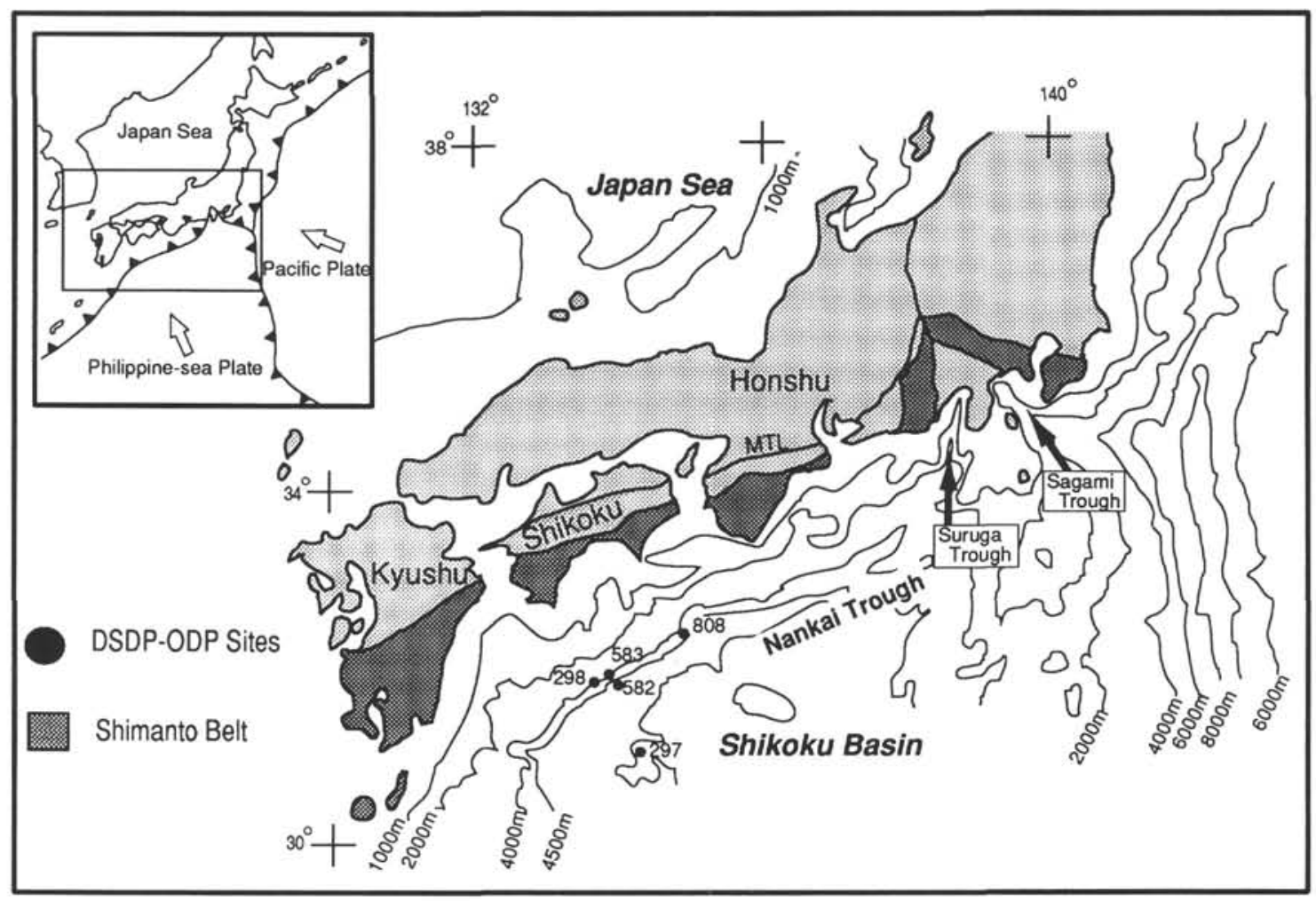

Figure 1. Location of ODP Leg 131, Site 808 at the Nankai Trough, and sites drilled during DSDP Legs 31 and 87.

\section{Permeability}

Fluid flow through the accretionary sediment column has numerous, significant effects. Advective transport of chemical species may dictate where dissolution and precipitation occur. Fluid flow is necessary for the physical compaction of sediments to take place under overburden and/or tectonic loads. Heat transport through advection also depends on the ability of fluids to find open paths through the complex.

Few permeability measurements have been reported for the modern marine environment in comparison to other physical parameters, largely because the former are difficult and time-consuming to make. The most extensive database is that contributed by the marine geotechnical community. Some indications of permeability have been provided through indirect approaches, such as those regulating diffusion profiles of interstitial pore fluids. Bryant et al. (1981) presented an early summary of marine sediment permeability data obtained though geotechnical testing of samples under laboratory conditions. Silva et al. (1981) found permeabilities ranging from $10^{-6}$ to $10^{-9} \mathrm{~cm} / \mathrm{s}$ for pelagic red clays from the northwest Pacific. Schulthiess et al. (1985) measured in-situ pore pressures from which permeabilities were estimated from the tidal response of pore fluids. Taylor (1992) described numerous measures of geotechnical properties from successions of downhole samples from both a red clay and a hemipelagic carbonate environment. Pittenger and Taylor (1989) described a strong lithologic control on permeability dictated by the concentration of biogenic silica in nonlithified hemipelagic sediments. Taylor and Bryant (1985) made several measurements of sediment permeability of samples from the Middle America trench and Leonard and Bryant (in press) completed a suite of tests on sediments from the Vanuatu margin.

Increasingly, the quantification of permeability in the marine environment has been attempted at different scales. Intergranular (matrix) permeability may dominate at a scale of tens of meters in homogeneous formations, although permeability anisotropy is common at this scale.
Bulk formation permeability, which includes fractures in a rock sequence, may be significantly greater than the intergranular permeability measured in hand and core samples. Measurements of bulk permeability must be made in-situ. The differences between different forms of permeability must be understood before laboratory data are interpreted in terms of the natural accretionary system.

In-situ measurements of permeability were attempted during the cruise utilizing different packer configurations, but were unsuccessful (Taira, Hill, Firth, et al., 1991). In-situ measurements of permeability were also calculated from a new instrument deployed during Leg 131; the LAST-1 (see Moran, this volume). These tests provide an indication of matrix permeability under in-situ conditions.

\section{DSDP Legs 31 and $87 \mathrm{~A}$}

Drilling and coring at three sites $(298,582$, and 583) around the toe of the Nankai accretionary prism were conducted during previous Deep Sea Drilling Project (DSDP) Legs 31 and 87A (Fig. 1). Site 583 is located at the frontal fault terrace of the trench slope; sampling there reached $450 \mathrm{~m}$ below seafloor (mbsf). Site 582, situated approximately $2 \mathrm{~km}$ seaward of the deformation front in the $15 \mathrm{~km}$-wide zone of undeformed trench fill, was drilled and cored as a reference site with penetration of about $750 \mathrm{mbsf}$. Site 298 , located approximately $27 \mathrm{~km}$ west and arcward of Site 583, was noncontinously cored to 611 mbsf. Physical properties measurements on samples from these sites consisted of water content determinations made aboard the drill ship, and bulk density, porosity, and grain density measurements made in shore-based laboratories after the cruise.

Studies of the consolidation characteristics of accretionary sediments elucidate tectonic deformation processes within this convergent margin and provide information about sediment matrix permeability at the three sites (Trabant et al., 1975; Johns, 1986). Sediment permeabilities reported from DSDP Site 583 ranged from $1.32 \times 10^{-6}$ to $4.74 \times 10^{-6}$ $\mathrm{cm} / \mathrm{s}\left(1.32-4.74 \times 10^{-15} \mathrm{~m}^{2}\right)$ for samples from 22 to $23 \mathrm{mbsf}$. 

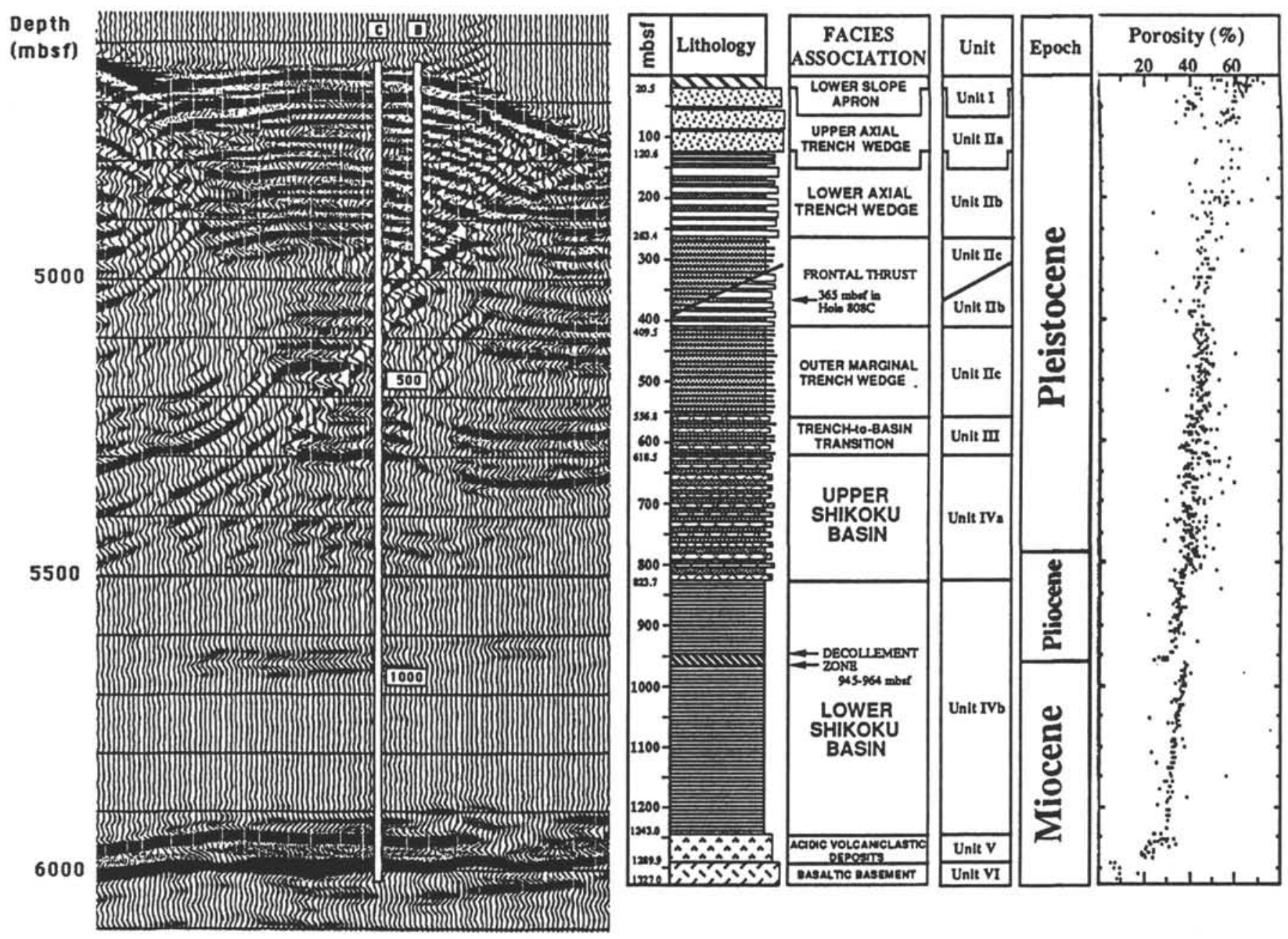

Figure 2. Seismic profile, lithologic summary, and porosity at the location of Site 808 .

\section{METHODS}

Permeability measurements described in this paper were performed on subsamples of cores collected during ODPLeg 131. These subsamples were taken adjacent to shipboard physical properties samples. Seven whole-round samples were selected specifically for permeability measurements, and 37 smaller samples selected for microfabric studies also were tested for permeability. Six additional whole-round samples were chosen for laboratory consolidation tests, providing a total of 50 samples distributed over the length of the cored interval at Site 808 (Table 1). All samples were marked with arrows to indicate their orientation relative to the core direction. The samples were carefully wrapped in plastic, waxed, and placed in sealed plastic bags with wet sponges, and were hand-carried back to the laboratory. Samples were checked for breakage and signs of drying before testing and suspect samples were not used.

Permeability is expressed in this study as the coefficient of permeability $(k)$ with an approximate equivalent value of specific permeability provided in parenthesis. Permeabilities were measured along the core axis $\left(k_{v}\right)$ or across the core diameter $\left(k_{h}\right)$. These coefficients are related to specific, or absolute, permeability through the following equation:

$$
K=k \mu / \gamma
$$

where $\mu$ and $\gamma$ are the viscosity of the permeant and unit weight, respectively. Approximate conversions of the coefficient of perme- ability to absolute permeability are provided below, recognizing that accurate conversion requires considering viscosity and unit weight:

$$
\begin{gathered}
1 \mathrm{~cm}^{2}=10^{-5} \mathrm{~cm} / \mathrm{s} \\
1 \mathrm{~m}^{2}=10^{-9} \mathrm{~cm} / \mathrm{s} \\
1 \text { Darcy }=10^{-3} \mathrm{~cm} / \mathrm{s}
\end{gathered}
$$

\section{Direct Measures}

Permeability measurements in the laboratory were achieved in two manners: through direct measurement of flow under known head and indirectly from the rate of consolidation to a known applied stress. Most direct measures of permeability were developed in the geotechnical field (Lambe, 1969; Zimmie and Riggs, 1981). This study utilized constant head and constant flow techniques. The constant head method was used on sample plugs, whereas the constant flow method was used on several whole-round consolidation samples tested at the Texas A\&M shore-based laboratory. All tests utilized seawater as the fluid medium to avoid osmotic effects. Laboratory temperature was also monitored to account for viscosity changes.

Constant head tests were done following the standard test method ASTM D-2434, with the following modifications:

1. Seawater was used, 
Table 1. Summary of the results from permeability testing of sediments from Site 808 .

\begin{tabular}{|c|c|c|c|c|c|c|c|c|c|}
\hline $\begin{array}{l}\text { Hole, core, } \\
\text { section }(\mathrm{cm})\end{array}$ & $\begin{array}{l}\text { Depth } \\
\text { (mbsf) }\end{array}$ & Test $^{a}$ & $\begin{array}{c}k \text { (horiz) } \\
(\mathrm{cm} / \mathrm{s})\end{array}$ & $\begin{array}{c}\text { Temperature } \\
\left({ }^{\circ} \mathrm{C}\right)\end{array}$ & Salinity & $\begin{array}{c}k(\text { vert }) \\
(\mathrm{cm} / \mathrm{s})\end{array}$ & $\begin{array}{c}\text { Temperature } \\
\left({ }^{\circ} \mathrm{C}\right)\end{array}$ & Salinity & Porosity (\%) \\
\hline \multicolumn{10}{|l|}{$131-$} \\
\hline $808 \mathrm{~A}-1 \mathrm{H}-3,140$ & 3.24 & W & & & & $6.32 \mathrm{e}-06$ & & & 65.8 \\
\hline $808 G-8 X-3$ & 196.00 & M & & & & $3.00 \mathrm{e}-05$ & & 0 & \\
\hline $808 \mathrm{G}-8 \mathrm{X}-3,25$ & 196.25 & w & & & & $1.58 \mathrm{e}-05$ & & & 50.2 \\
\hline $808 \mathrm{~B}-16 \mathrm{X}-1,125$ & 255.45 & W & & & & $5.89 \mathrm{e}-06$ & & & 46.2 \\
\hline $808 \mathrm{C}-3 \mathrm{R}-1,45$ & 318.05 & $\mathrm{P}$ & $6.37 e-08$ & 19 & 26.5 & & & & 42.6 \\
\hline $808 \mathrm{C}-6 \mathrm{R}-1$ & 347.00 & TS & & & & $4.60 e-10$ & & & \\
\hline $808 \mathrm{C}-6 \mathrm{R}-1$ & 347.00 & M & & & & $3.00 e-09$ & & & \\
\hline $808 \mathrm{C}-6 \mathrm{R}-1,116$ & 347.76 & $\mathrm{P}$ & & & & $1.19 e-07$ & 22 & 26.5 & 47.5 \\
\hline $808 \mathrm{C}-10 \mathrm{R}-2,48$ & 387.18 & $\mathrm{P}$ & $5.39 \mathrm{e}-08$ & 22 & 26.5 & & & & 39.4 \\
\hline $808 \mathrm{C}-12 \mathrm{R}-2,55$ & 406.65 & $\mathrm{P}$ & $9.96 \mathrm{e}-08$ & 17 & 26.5 & & & & 47.1 \\
\hline $808 \mathrm{C}-14 \mathrm{R}-2,38$ & 425.88 & $\mathrm{P}$ & $1.16 \mathrm{e}-07$ & 22 & 26.5 & & & & 44.2 \\
\hline $808 \mathrm{C}-18 \mathrm{R}-4,10$ & 467.00 & $\mathrm{P}$ & $5.03 e-08$ & 19 & 26.5 & & & & 46.6 \\
\hline $808 \mathrm{C}-18 \mathrm{R}-4,10$ & 467.00 & $\mathrm{P}$ & $9.93 \mathrm{e}-08$ & 21 & 26.5 & & & & \\
\hline $808 \mathrm{C}-25 \mathrm{R}-1,4$ & 530.94 & $\mathrm{P}$ & $9.41 \mathrm{e}-08$ & 21 & 26.5 & & & 43.8 & \\
\hline $808 \mathrm{C}-29 \mathrm{R}-7,8$ & 577.68 & $\mathrm{P}$ & & & & $2.46 e-07$ & 21 & 25 & 42.0 \\
\hline $808 \mathrm{C}-29 \mathrm{R}-7,8$ & 577.68 & $\mathbf{P}$ & & & & $2.63 e-07$ & 20 & 25 & \\
\hline $808 C-33 R-3,105$ & 607.95 & $\mathrm{P}$ & $5.00 \mathrm{e}-09$ & 17 & 26.5 & $6.42 \mathrm{e}-08$ & 18 & 24.3 & 37.3 \\
\hline $808 \mathrm{C}-37 \mathrm{R}-1,50$ & 646.00 & $\mathrm{P}$ & $4.41 \mathrm{e}-08$ & 22 & 26.5 & & & & 37.0 \\
\hline $808 \mathrm{C}-39 \mathrm{R}-1,93$ & 665.43 & $\mathrm{P}$ & $1.03 \mathrm{e}-07$ & 19 & 26.5 & $8.87 \mathrm{e}-08$ & 20 & 24.3 & 40.8 \\
\hline $808 \mathrm{C}-40 \mathrm{R}-1,105$ & 675.25 & $\mathrm{P}$ & $1.81 \mathrm{e}-08$ & 20 & 24.3 & $2.23 \mathrm{e}-08$ & 20 & 24.3 & 38.0 \\
\hline $808 \mathrm{C}-45 \mathrm{R}-1,36$ & 722.36 & $\mathrm{P}$ & $2.40 \mathrm{e}-07$ & 20 & 24.3 & & & 39.7 & \\
\hline $808 \mathrm{C}-45 \mathrm{R}-1,36$ & 722.36 & $\mathrm{P}$ & $2.29 \mathrm{e}-07$ & 19 & 26.5 & $4.91 \mathrm{e}-08$ & 20 & 24.3 & 39.7 \\
\hline $808 \mathrm{C}-50 \mathrm{R}-4,106$ & 775.96 & $\mathrm{P}$ & $5.85 \mathrm{e}-06$ & 20 & 26.5 & $3.05 \mathrm{e}-08$ & 20 & 26.5 & 41.8 \\
\hline $808 C-5 I R-5,98$ & 787.08 & $\mathrm{P}$ & $2.70 e-08$ & 19 & 26.5 & $3.15 \mathrm{e}-08$ & 20 & 24.3 & 38.9 \\
\hline $808 C-51 R-5,98$ & 787.08 & $\mathrm{P}$ & & & & $9.94 c-08$ & 20 & 24.3 & 38.9 \\
\hline $808 C-52 R-2,118$ & 792.46 & $\mathrm{P}$ & $1.12 \mathrm{e}-08$ & 20 & 24.3 & $1.06 \mathrm{e}-08$ & 20 & 24.3 & 39.9 \\
\hline $808 C-53 R-3,23$ & 802.63 & $\mathrm{P}$ & $1.18 \mathrm{e}-06$ & 21 & 25 & & & & \\
\hline $808 C-53 R-3,23$ & 802.63 & $\mathrm{P}$ & $1.04 \mathrm{e}-06$ & 20 & 25 & & & & \\
\hline $808 \mathrm{C}-54 \mathrm{R}-6,118$ & 817.78 & $\mathrm{P}$ & $3.29 \mathrm{e}-08$ & 20 & 24.3 & $7.07 e-08$ & 20 & 24.3 & 35.7 \\
\hline $808 \mathrm{C}-55 \mathrm{R}-1,98$ & 819.68 & $\mathrm{P}$ & $1.11 e-07$ & 19 & 26.5 & $4.59 \mathrm{e}-08$ & 21 & 26.5 & 36.6 \\
\hline 808C-55R-3, 105 & 822.75 & $\mathrm{P}$ & $3.08 \mathrm{e}-09$ & 20 & 26.5 & $1.17 \mathrm{e}-08$ & 19 & 26.5 & 36.8 \\
\hline $808 C-55 R-3,105$ & 822.75 & $\mathrm{P}$ & & 21 & 26.5 & $1.01 \mathrm{e}-08$ & & 36.8 & \\
\hline $808 C-55 R-5,97$ & 825.67 & $P$ & $2.09 \mathrm{e}-09$ & 17 & 26.5 & $2.99 \mathrm{e}-08$ & 20 & 24.3 & 35.8 \\
\hline $808 \mathrm{C}-56 \mathrm{R}-1,142$ & 829.82 & $\mathrm{P}$ & $1.08 \mathrm{e}-08$ & 20 & 24.3 & $3,43 \mathrm{e}-08$ & 20 & 24.3 & 31.0 \\
\hline $808 \mathrm{C}-62 \mathrm{R}-1,78$ & 886.88 & $\mathrm{P}$ & $1.08 \mathrm{e}-08$ & 20 & 26.5 & $4.22 \mathrm{e}-09$ & 20 & 26.5 & 34.0 \\
\hline $808 C-63 R-2,80$ & 898.20 & $\mathrm{P}$ & & & & $2.59 \mathrm{e}-08$ & 17 & 24.3 & 31.7 \\
\hline $808 \mathrm{C}-66 \mathrm{R}-3,118$ & 928.98 & $\mathrm{P}$ & & & & $1.00 \mathrm{e}-08$ & 17 & 24.3 & 32.5 \\
\hline $808 \mathrm{C}-69 \mathrm{R}-2,108$ & 956.38 & $\mathrm{P}$ & $6.95 e-08$ & 20 & 24.3 & $1.57 \mathrm{e}-07$ & 17 & 24.3 & 27.7 \\
\hline $808 \mathrm{C}-70 \mathrm{R}-1,5$ & 963.45 & $\mathrm{P}$ & $7.78 \mathrm{e}-10$ & 20 & 26.5 & & & & \\
\hline $808 \mathrm{C}-70 \mathrm{R}-4,135$ & 969.25 & $\mathrm{P}$ & & & & $1.32 \mathrm{e}-08$ & 17 & 24.3 & 38.1 \\
\hline $808 \mathrm{C}-72 \mathrm{R}-4,28$ & 984.58 & $\mathrm{P}$ & & & & $5.02 \mathrm{e}-06$ & 17 & 24.3 & 36.6 \\
\hline $808 C-73 R-3,147$ & 996.57 & $\mathrm{P}$ & & & & $5.97 \mathrm{e}-08$ & 21 & 25 & 36.8 \\
\hline $808 C-73 R-3,147$ & 996.57 & $\mathbf{P}$ & & & & $5.98 \mathrm{e}-08$ & 20 & 25 & \\
\hline $808 \mathrm{C}-75 \mathrm{R}-2,34$ & 1013.17 & $\mathrm{P}$ & $3.67 \mathrm{e}-10$ & 17 & 26.5 & & & 36.4 & \\
\hline $808 \mathrm{C}-77 \mathrm{R}-4,28$ & 1034.72 & $\mathrm{P}$ & & & & $2.43 e-08$ & 17 & 24.3 & 35.2 \\
\hline $808 \mathrm{C}-78 \mathrm{R}-2,112$ & 1041.70 & $\mathrm{P}$ & $2.73 e-09$ & 20 & 25 & & & 34.5 & \\
\hline $808 \mathrm{C}-80 \mathrm{R}-1,128$ & 1059.07 & $\mathrm{P}$ & $7.39 \mathrm{e}-07$ & 22 & 26.5 & & 18 & 26.5 & 34.5 \\
\hline $808 \mathrm{C}-80 \mathrm{R}-1,128$ & 1059.07 & $P$ & $2.87 e-07$ & 18 & 26.5 & & & & \\
\hline $808 \mathrm{C}-84 \mathrm{R}-1,97$ & 1092.94 & $\mathrm{P}$ & & & & $3.41 \mathrm{e}-08$ & 17 & 24.3 & 33.0 \\
\hline $808 \mathrm{C}-85 \mathrm{R}-1$ & 1098.30 & $\mathrm{~K}$ & & & & $2.94 \mathrm{e}-07$ & & 35 & \\
\hline $808 \mathrm{C}-95 \mathrm{R}-1,13$ & 1194.70 & $\mathrm{P}$ & & & & $1.09 \mathrm{e}-07$ & 21 & 25 & 29.7 \\
\hline $808 \mathrm{C}-95 \mathrm{R}-1,13$ & 1194.70 & $\mathrm{P}$ & & & & $7.94 \mathrm{e}-08$ & 20 & 25 & \\
\hline
\end{tabular}

2. A pressurized head system using nitrogen gas was used to force the permeant through samples at pressures between $140-275 \mathrm{kPa}$ (20-40 psi), and

3. Samples were wrapped in Saran Wrap ${ }^{\mathrm{TM}}$ leaving the top and bottom open and placed in the center of a plastic cylindrical holder ( $3.5 \mathrm{~cm}$ high, $5.0 \mathrm{~cm}$ diameter) in which the void between the sample and cylinder walls was filled with modeling clay.

A blank sample was prepared in the same fashion using a modeling clay plug to test for possible leakage around the wall of the container or along the sides of the sample. The blank had no flow after $72 \mathrm{hr}$ at a head of $275 \mathrm{kPa}$ ( $40 \mathrm{psi}$ ). A total of 60 permeability measurements were made using this arrangement, providing values of permeability along the axis of the core (vertical) and across the diameter of the core (horizontal). Ten samples were tested twice, including repeating the steps for sample preparation. The average difference between measured coefficients of permeability in nine of these samples was $4 \times$ $10^{-8} \mathrm{~cm} / \mathrm{s}$ over the range of $1.18 \times 10^{-6}$ and $1.01 \times 10^{-8} \mathrm{~cm} / \mathrm{s}$ (Table 1 ). All plug tests represent flow conditions through the sample without a superimposed load. Applied loads reduce permeability as the void ratio decreases; however, extrapolation of laboratory measurements to in-situ conditions requires making assumptions regarding the original stress condition and pore pressure. This extrapolation was not attempted for the falling-head samples.

Permeabilities measured at Texas A\&M were obtained using a syringe pump system as described by Olsen et al. (1985). This method applies a continuous, known flow rate of permeant through the sample while the resultant head differential across the sample is measured 
with a pressure transducer. Several flow rates were used for each test, resulting in a flow rate vs. differential pressure curve, from which the coefficient of permeability is determined (Fig. 3). Tests were run following the completion of specific load from consolidation testing; hence, coefficients of permeability are provided for various stages of consolidation.

\section{Indirect Measures}

Soil mechanics practitioners have modeled the response of soils (or sediments) to superimposed stresses (Terzaghi, 1943; Lambe, 1969). The rate of response to an imposed stress depends, in part, on the ability of fluid to leave or enter the particulate system. Hence, the coefficient of permeability is directly linked to soil response through the models that describe sediment stress-strain behavior. The rate of volume change of a sediment in response to an imposed stress is commonly described in terms of the coefficient of consolidation $\left(c_{v}\right)$. The coefficient of permeability, in turn, is related to $c_{v}$ through the following equation:

$$
k=c_{v} / M_{v} A
$$

where $M_{v}$ is the coefficient of solid compressibility and $A$ is the area of drainage for the sample.

Shortcomings of the indirect measurements lie principally in how well a given model describes sediment stress-strain relationships. Direct and indirect measures typically vary by about one order of magnitude, with the direct measure being the greater of the two. We believe that direct measurements provide a better estimate of permeability.

\section{RESULTS}

While most of the measurements of permeability made in this study are from sediments collected below 320 mbsf, several samples were obtained from the upper section. The upper two sedimentary units at Site 808 , consisting mostly of sandy to silty turbidites, are characterized by contrasting physical properties (see porosity trend, Fig. 2). The permeability of this upper section is quite variable and locally high, as the sands layers are uncemented. Three samples tested from this upper section were consolidation samples. The coefficients of vertical permeability of these samples, at their lowest confining pressure, ranged from $1.58 \times 10^{-5}$ to $5.89 \times 10^{-6} \mathrm{~cm} / \mathrm{s}\left(1.58 \times 10^{-14}\right.$ to $5.89 \times 10^{-15} \mathrm{~m}^{2}$ ) (Table 1, Fig. 4).

The coefficients of horizontal permeability for samples extending from $320 \mathrm{mbsf}$ to $950 \mathrm{mbsf}$ (the décollement) exhibit an overall slight decrease with increasing depth (Fig. 4). The coefficients of permeability gradually decrease from about $10^{-7} \mathrm{~cm} / \mathrm{s}\left(10^{-16} \mathrm{~m}^{2}\right)$ at $320 \mathrm{mbsf}$ to $10^{-8} \mathrm{~cm} / \mathrm{s}\left(10^{-17} \mathrm{~m}^{2}\right)$ above the décollement. This trend also is evident in the vertical coefficients, although these are greater overall by half an order of magnitude. Two samples revealed vertical permeability coefficients in excess of $10^{-6} \mathrm{~cm} / \mathrm{s}\left(10^{-15} \mathrm{~m}^{2}\right)$ : Sample 131$808 \mathrm{C}-50 \mathrm{R}-4(106 \mathrm{~cm})$ and $-72 \mathrm{R}-4(28 \mathrm{~cm})$. The former sample is of silty mudstone in which the measure of permeability was done along the bedding plane. The latter sample is a mottled mudstone of low porosity $(36 \%)$, and the high permeability may be an artifact of a microcracking, although none was observed.

Below the décollement, both $k_{v}$ and $k_{h}$ generally increase with depth, although only a few samples were tested from this interval (Table 1, Fig. 4). The coefficients of permeability in both directions is about $5 \times 10^{-8} \mathrm{~cm} / \mathrm{s}\left(5 \times 10^{-17} \mathrm{~m}^{2}\right)$, with some high variations around this average. The lowest value of $k_{h}$ measured in these tests was 3.67 $\times 10^{-10} \mathrm{~cm} / \mathrm{s}\left(3.67 \times 10^{-19} \mathrm{~m}^{2}\right)$ for the sample from $1014 \mathrm{mbsf}$.

The laboratory tests of permeability performed at different effective loads through consolidation testing reveal the relationship between the coefficient of permeability and void ratio for these sediments (Fig. 5). The uppermost sample, from $3.2 \mathrm{mbsf}$, was within lithologic Unit I which consists of a hemipelagic mud with evidence of slumps and

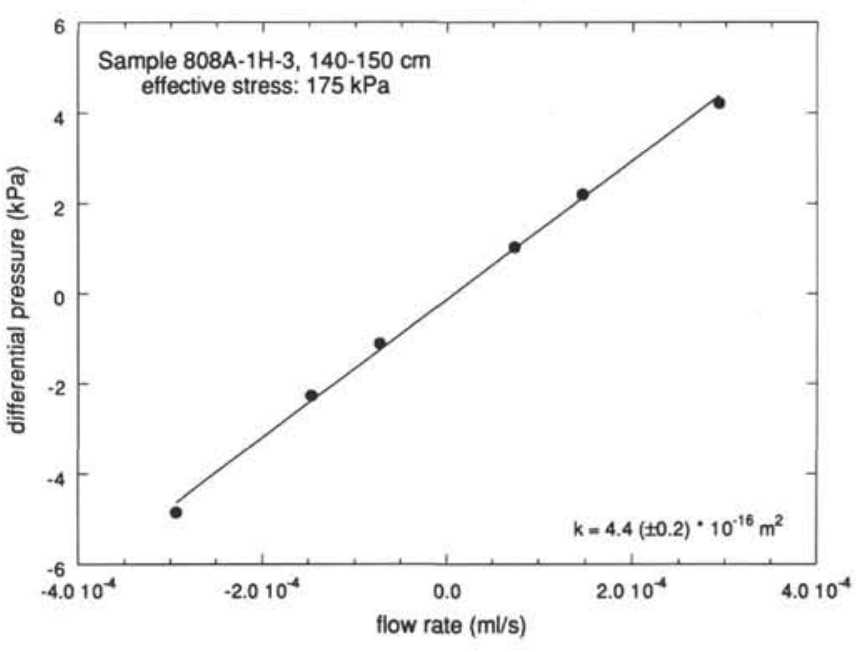

Figure 3. Example of permeability measurement using the constant-flow technique. Different flow rates result in pressure differentials across the sample, that in turn are a function of permeability (Sample 131-808A-1H-3, $140-150 \mathrm{~cm})$.

turbidites. Samples 131-808G-8X-3 (24 cm) (196 mbsf) and -808B$16 \mathrm{X}-1(123 \mathrm{~cm})(255 \mathrm{mbsf})$ were from lithologic Unit III, consisting of thin bedded sand and silt turbidites. The relationship of permeability to void ratio is different for samples from lithologic Units I and III. Further tests from these two units, combined with sediment texture data, are required to verify and explain these differences.

Results from all permeability tests undertaken as part of this study are plotted against sediment void ratio in Figure 6. The three wholeround samples yielded independent permeability-void curves, as these samples were tested over a range of effective stresses and void ratios. The whole-round samples generally had higher void ratios than the fabric plugs (largely reflecting the shallower depths of origin for the former), but the whole-round samples also yielded permeability-void ratio curves with higher slopes than for the data set overall (Fig. 6). This difference probably reflects the greater silt and sand content of the fabric samples, and in-situ consolidation state and relative youth of the whole-round samples.

Figure 7 illustrates permeability anisotropy, determined from the difference between horizontal and vertical permeability in the fabric samples, divided by the average permeability $\left[200 \times\left(k_{h}-k_{v}\right) /\left(k_{h}\right.\right.$ $\left.\left.+k_{y}\right)\right]$. The data are too scattered to yield a strong trend, but there does seem to be a general change from more positive values (higher relative horizontal permeability) to more negative values (higher relative vertical permeability) with increasing depth and decreasing void ratio. This trend is also apparent if the permeability results for individual lithologic units are averages. At first this result seems surprising, as horizontal permeability should become more important following compaction under a vertical load (e.g., with increasing burial). Our experimental results may reflect an increase with depth (and age) in sample rotation about a horizontal axis during accretion and subsequent thrusting. This rotation should also influence permeability anisotropy resulting from the deposition of coarse sand layers, which could be significantly more important to large-scale fluid flow through the Nankai accretionary complex.

\section{DISCUSSION}

There have been relatively few permeability measurements made on marine sediments from active convergent margins. The measurements made for this study provide a measure of intergranular permeability and thus are a lower bound to formation or bulk permeability. An increase in bulk permeability may occur through fracturing, faulting, and temporal events, such as postulated for slip drainage at 


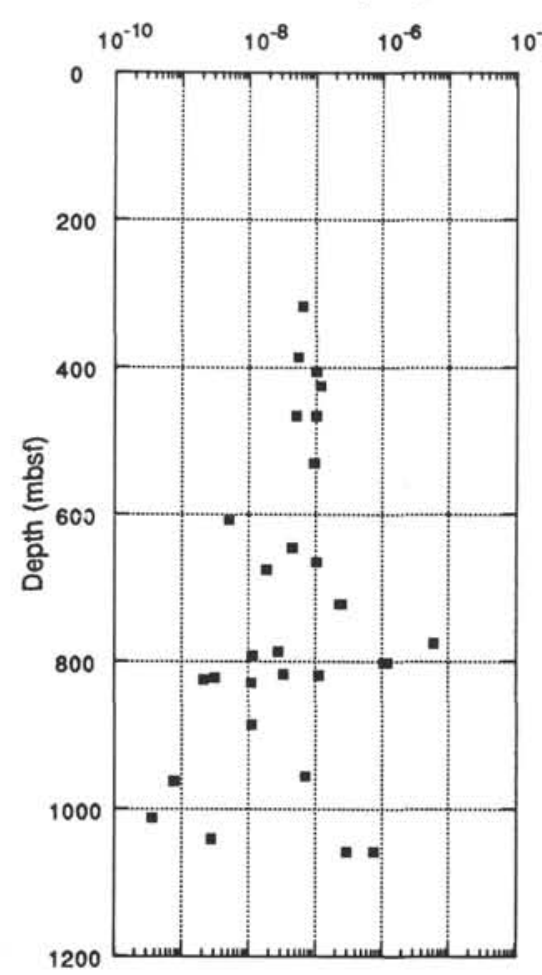

$$
10^{-4}
$$

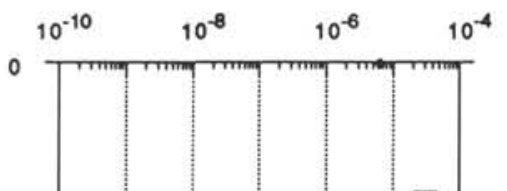

200
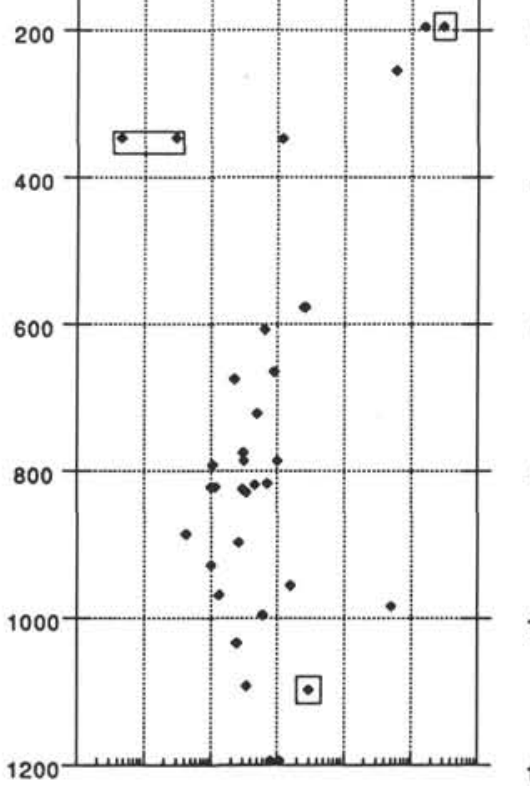

Values in boxes are from other studies (see Table 1)
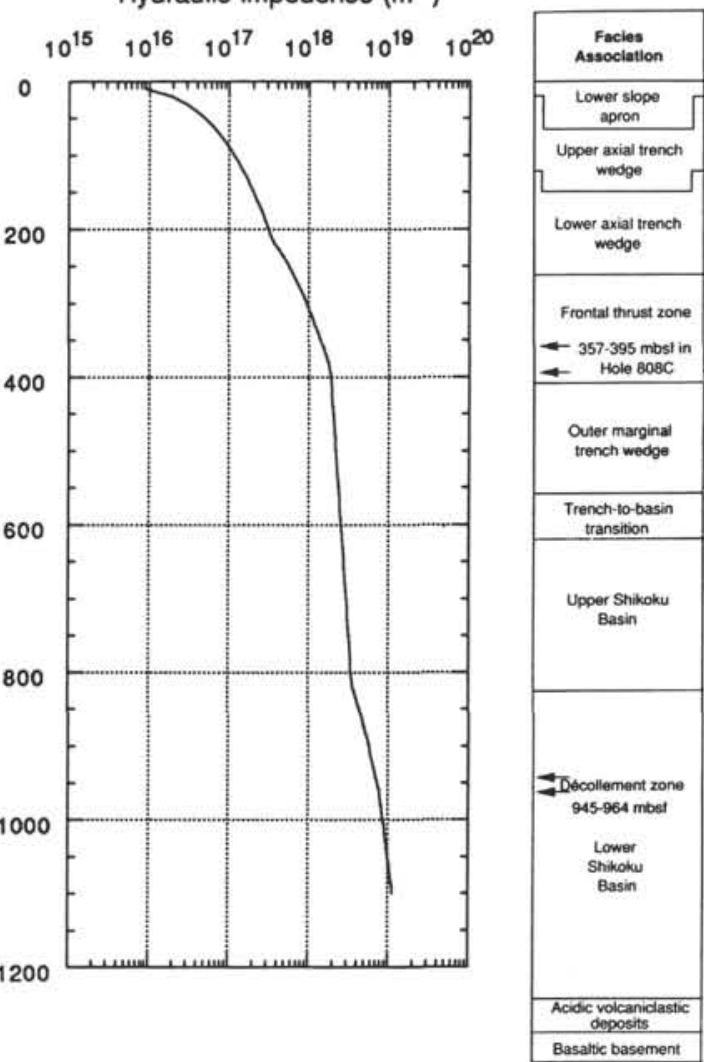

Figure 4. Downhole distribution of measured coefficients of permeability and of hydraulic impedance (for the vertical thickness of the sediment section) at Site 808. The impedance calculation is explained in the text.

the Barbados accretionary complex décollement, during periods of overpressuring (Moore et al., 1988). Low formation permeability can result from the presence of localized layers or zones of clay-rich sediment such as at the décollement at Nankai and above the décollement at Barbados (Taylor and Leonard, 1990).

\section{Permeability Structure}

Two major structural features were cored at Site 808: a major thrust fault within the accreted section (360-390 mbsf) and the décollement ( $945-965$ mbsf) which separates the offscraped section from subducted sediments. The thrust fault was distinguished in cores by significant fracturing and overturned beds having facilitated approximately $145 \mathrm{~m}$ of stratigraphic throw. This fault separates a repeated stratigraphic section bearing remarkably similar physical properties.

The topmost $400 \mathrm{~m}$ of sediment at Site 808 (Units I and II) comprises the upper thrust package at this location on the lower slope. The package is dominated by thick-bedded, sand to silt turbidites. The distinctive bimodal character of most physical properties in this upper section corresponds to an equivalent bimodal composition of turbidites. This characteristic is most obvious in the porosities of Unit I, and is significantly reduced in Unit II where finer-grained sediment dominate (Fig. 2). Permeability measurements in silty sediments from this upper package are about $10^{-5}$ to $10^{-6} \mathrm{~cm} / \mathrm{s}\left(10^{-14}\right.$ to $\left.10^{-15} \mathrm{~m}^{2}\right)$ (Fig. 4). These values corroborate the measurements made through the indirect method (from consolidation rates) at Site 583 (Johns, 1986). This portion of the accretionary prism must drain freely as a large portion of the section consists of sand and sandy silt.

Smaller scale downhole porosity trends in the tectonic package between the major thrust fault and décollement characterize lithologic Subunits IIc, III, and IVa. These small differences are not evident from the fewer permeability measurements from this site. The repeated stratigraphic section below the thrust fault at approximately 390 mbsf does not show a significant reduction in porosity relative to its equivalent section above the fault; instead, the thrust fault marks the depth at which the downhole compaction trend, developed in the overlying section, is reset (Fig. 2). The observation that sediments below the fault do not appear to have consolidated from the additional load suggests that dewatering in this section has been minimal, either due to very low bulk permeability or because faulting is recent. With coefficients of matrix permeability near $10^{-7} \mathrm{~cm} / \mathrm{s}$ $\left(10^{-16} \mathrm{~m}^{2}\right)$, the observed trend in porosity may be explained by a combination of both factors.

Permeabilities through most of lithologic Units IV and V follow the general porosity trend, reflecting a likely combination of consolidation and a finer-grained texture. This 550-m-thick section has coefficients of permeability less than $10^{-7} \mathrm{~cm} / \mathrm{s}\left(10^{-16} \mathrm{~m}^{2}\right)$; these values are low enough to allow formation of overpressures during tectonic loading. These permeability coefficients are similar in magnitude to those found in the accreted packages of fine-grained sediments from the toe of the Barbados complex on ODP Leg 110 (Taylor and Leonard, 1990).

The décollement is an approximately 20 -m-thick zone between 945 and 965 mbsf. Although no significant lithologic compositional changes occur across this feature, there is a pronounced and extremely delineated contrast in porosities in the overlying and underthrust sediments. Porosities are near $40 \%$ above the décollement, decrease to near $30 \%$ within this fault plane, and then increase to over $50 \%$ below the décollement. This significant contrast in porosity must mark distinctive consolidation histories of the accreted vs. subducted sediments. No conclusive evidence exists as to whether the décollement alone is overpressured, or if instead the entire subducted section has 

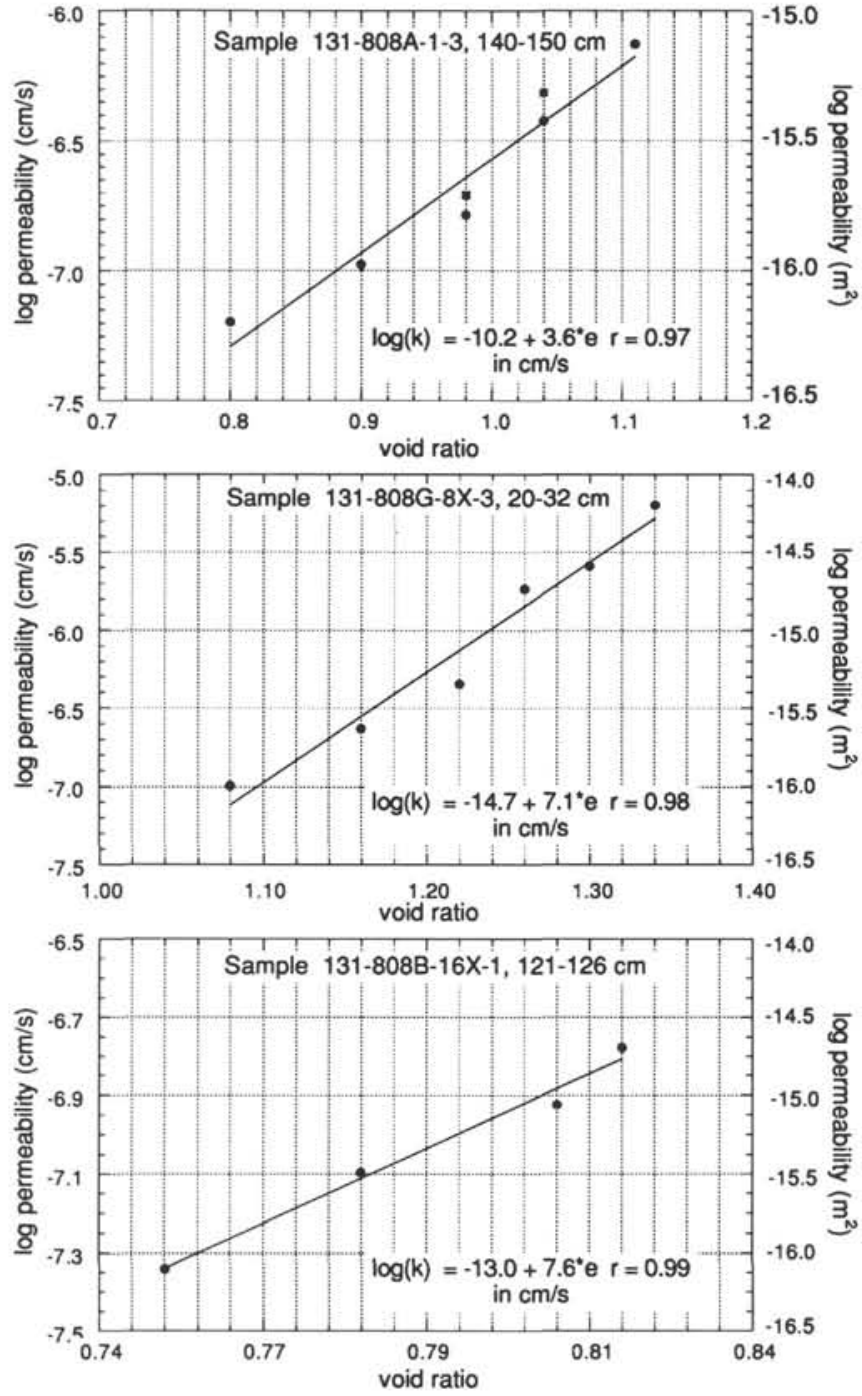

Figure 5. Measurements made at several stages of sample consolidation reveal the relationship between void ratio and permeability for the sediments of Site 808 .

experienced excess pore pressure. The fault plane, however, may impede fluid flow as the extremely low porosities measured in these sheared sediments most likely correlate with extremely low permeability. Permeabilities in this section ranged from $10^{-7}$ to $10^{-10} \mathrm{~cm} / \mathrm{s}$ $\left(10^{-16}\right.$ to $\left.10^{-19} \mathrm{~m}^{2}\right)$. This difference of three orders of magnitude reflects the variable permeability resulting from the heterogeneous structure of this zone, or matrix vs. fracture permeability of the sediment samples. This variability may be accentuated at a formation scale depending on the state of stress-strain at this depth as fractures open and close. The permeability measured in a sample from the Barbados prism, from within $20 \mathrm{~m}$ of the décollement, was close to $10^{-12} \mathrm{~cm} / \mathrm{s}\left(10^{-21} \mathrm{~m}^{2}\right)$.

The subducted sediments at Site 808 revealed higher porosities than those immediately above the décollement (Fig. 2). The matrix permeabilities in this section are also quite low, ranging from $10^{-7}$ to $10^{-10} \mathrm{~cm} / \mathrm{s}\left(10^{-16}\right.$ to $\left.10^{-19} \mathrm{~m}^{2}\right)$ (Fig. 4). These low permeabilities, combined with a potentially low permeability horizon at the décollement, will resist dewatering and would bear excess pore pressures. Potential drainage paths for these subducted sediments may lie along isolated fractures or horizons of ash and fractured basalt underlying the sediment section.

\section{Hydraulic Impedance}

We have used the permeability-void ratio relationship defined in Figure 6 to calculate the vertical hydraulic impedance of the Site 808 sediment pile, based on the porosities determined on index properties samples during Leg 131 (Taira, Hill, Firth, et al., 1991). These data were not corrected for rebound or in-situ temperature, so the results of this analysis should yield an upper bound to the actual vertical hydraulic impedance. Vertical impedance also should be higher than horizontal impedance because of layered heterogeneities in grain size caused by turbidite deposition. Impedance was calculated using a modified version of the equation defined by Karato and Becker (1983):

$$
I=\sum_{Z=0}^{Z_{\max }} \frac{\Delta Z}{10^{-9} \times k}
$$

where $k$ is permeability (in $\mathrm{cm} / \mathrm{s}$ ), and $I$ is hydraulic impedance (in $1 / \mathrm{m})$. The impedance at any depth is thus calculated from the void ratio (porosity) data for the overlying sediments, after applying the permeability-void ratio transform from Figure 6 . The hydraulic impedance-depth relationship defined using the above equation is displayed in Figure 4. This curve demonstrates that a change in sediment thickness from 100 to 300 mbsf (200\%) results in an increase in impedance to vertical fluid flow of an order of magnitude $(1000 \%)$. The next order-of-magnitude increase in impedance requires an additional $750 \mathrm{~m}$ of sediment. Figure 8 illustrates a series of type curves for the hydraulic impedance along different length flow paths having constant permeability; these curves could be appropriate for flow along conduits (such as faults) through the accretionary complex. A comparison of these type curves and the vertical impedance profile in Figure 4 provides insight to the hydrogeology of the accretionary complex. For example, the impedance to vertical fluid flow at a depth of $300 \mathrm{mbsf}$ is approximately $10^{18} \mathrm{~m}^{-1}$. The same impedance to horizontal flow along a $200 \mathrm{~km}$ path requires permeability significantly lower than $10^{-12} \mathrm{~m}^{2}$ (1 Darcy), the maximum transient permeability required for the décollement at the Barbados accretionary complex to explain differences in thermal anomalies landward and seaward of the deformation front (Fisher and Hounslow, 1990). Hydraulic impedance of $10^{18} \mathrm{~m}^{-1}$ is attained along a flow path only about $10 \mathrm{~km}$ if permeability is $10^{-14} \mathrm{~m}^{2}$, however, as modeled by Wuthrich et al. (1990) for the Barbados complex.

Assuming that fluid flow through the complex is governed by Darcy's Law, then the tendency for fluid to follow any path will be determined by a combination of pressure and gravity forces, as:

$$
\mathrm{v}=-\frac{k}{\mu}(\nabla P+\rho \mathrm{g})
$$

(in vector form) where $\mu$ is fluid viscosity, $\rho$ is fluid density, and $\mathbf{g}$ is gravitational acceleration. Fluid flowing along a path that is perpendicular to the gravitational vector (e.g., horizontal) is moved forward by the pressure gradient only; fluid flowing with a component of upward movement must be driven by a pressure gradient sufficient to overcome the hydraulic impedance along the flow path, plus gravitational potential. In the case of the frontal thrust encountered at Site 808 , the largest possible pressure gradient should be the difference between lithostatic and hydrostatic pressures (or overburden stress) divided by the distance along the thrust from Site 808 to the seafloor. At the depth of the thrust, the maximum lithostatic stress (assuming zero pore pressure) is about $5.4 \times 10^{4} \mathrm{kPa}$ (Taira, Hill, Firth, et al., 1991). At the point where the thrust intersects the seafloor, the water depth is approximately $4.75 \mathrm{~km}$ (Moore et al., 1991), giving a 


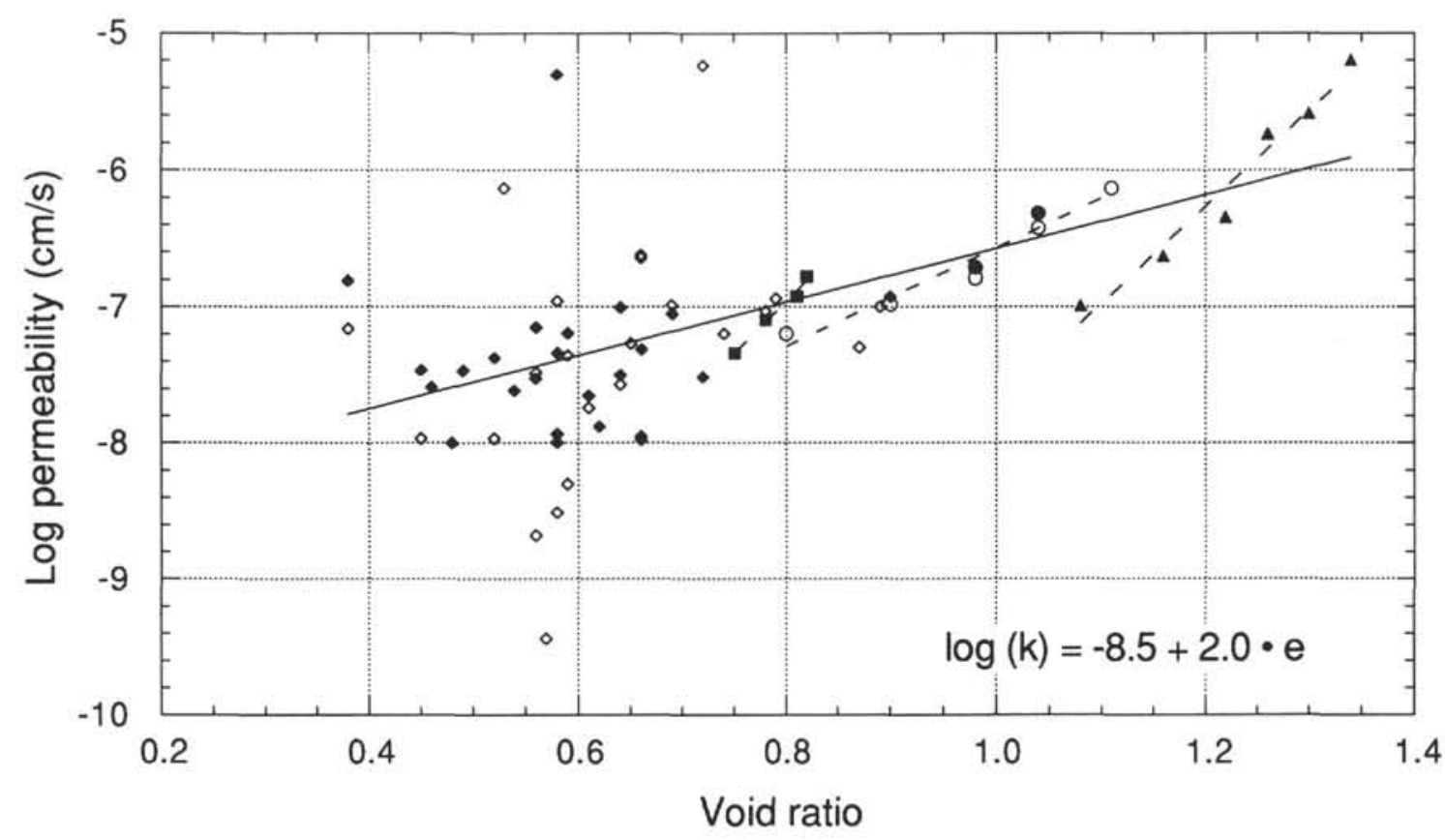

Figure 6. Log permeability vs. void ratio. Circles (131-808A-1H-3), squares (131-808B-16X-1), and triangles (131-808G-8X-3) represent results from testing of whole-round core samples; open circles are permeabilities calculated from consolidation coefficients determined during one-dimensional oedometer testing. All filled circles, squares, and triangles are permeabilities determined directly with a constant flow permeameter at a variety of consolidation states. Diamonds are permeability tests done on fabric plugs; open diamonds are horizontal permeabilities, filled diamonds are vertical permeabilities. The dashed lines are least-squares, best-fitting straight lines for individual whole round tests; the solid line is a least-squares, best-fitting straight line for all whole-round and vertical fabric tests, as defined by the equation displayed.

hydrostatic pressure of about $4.6 \times 10^{4} \mathrm{kPa}$. The path length along the thrust is about $0.7 \mathrm{~km}$, giving a maximum possible pressure gradient of about $11 \mathrm{kPa} / \mathrm{m}$. Assuming a thrust dip of $30^{\circ}$ (Taira, Hill, Firth, et al., 1990), the gravitational head gradient over this path is about $-5.1 \mathrm{kPa} / \mathrm{m}$ (with positive potential indicating an increase in the upward direction), and thus fluid flow along the thrust is possible, even if the pore fluid pressure is sufficiently below lithostatic. The maximum Darcy velocity along the thrust, assuming the head gradient above, fluid viscosity of $10^{-3} \mathrm{~Pa} / \mathrm{s}$, and a mean matrix permeability of $10^{-7} \mathrm{~cm} / \mathrm{s}\left(10^{-16} \mathrm{~m}^{2}\right.$, Fig. 6), is about $6 \times 10^{-10} \mathrm{~m} / \mathrm{s}$, or $2 \mathrm{~cm} / \mathrm{yr}$. Higher velocities are possible as a linear function of fault permeability.

Unfortunately, direct measurements of pore pressure and bulk permeability along the thrust were not obtained during Leg 131, and better estimates of bulk and conduit permeabilities await future studies. However, we can estimate the tendency of fluid to flow along particular paths, rather than directly upward to the seafloor, by considering the average matrix permeability $\left(10^{-7} \mathrm{~cm} / \mathrm{s}\right)$ near the frontal thrust (Fig. 4). The hydraulic impedance to vertical flow at this depth is $2 \times 10^{18} \mathrm{~m}^{-1}$, while the impedance to flow $700 \mathrm{~m}$ along the first thrust fault from Site 808 to the seafloor (Moore et al., 1990), is about $7 \times 10^{18} \mathrm{~m}^{-1}$ (Fig. 8). Given similar vertical and along-thrust head gradients (including pressure and gravity components), flow at Site 808 thus will not tend to be concentrated along the thrust unless permeability is significantly higher than that measured in the fabric samples from sediments surrounding the thrust.

\section{CONCLUSION}

The drilling programs led by DSDP and ODP have provided a rare glimpse into the earliest stages of sediment accretion and subduction. It is difficult to work in these environments as the complex geology and conditions challenge all attempts to core the sections. We have greatly improved our knowledge of the convergence process, and have begun to collect information on sediment physical properties that are key to continued modeling efforts. Another goal remains to be tackled; to measure in-situ physical properties, permeability, pore pressure, and stress-strain relationships. Development of special downhole tools and experiments ultimately will provide these data. Future drilling attempts at convergent margins should strive to achieve these measurements.

\section{ACKNOWLEDGMENTS}

This project benefited from the input of several reviewers, including Roy Wilkens. Results from our colleagues in Wales and New York helped to round out this manuscript. In particular, Emma Stephenson (Wales) was instrumental in obtaining those results. Our thanks go to the crew of the JOIDES Resolution, who prevailed amidst adversity to obtain this unique core section, and to the members of the JOIDES panels for their continued efforts to promote research in this frontier area. This research was supported by USSAC grants 20451 (AF) and 20467 (ET). Acknowledgment also is made to the donors of the Petroleum Research Fund, administered by the ACS, for partial support (AF).

\section{REFERENCES*}

Bray, C.J., and Karig, D.E., 1986. Physical properties of sediments from the Nankai Trough, Deep Sea Drilling Project Leg 87A, Sites 582 and 583. In Kagami, H., Karig, D.E., Coulbourn, W.T., et al., Init. Repts. DSDP, 87: Washington (U.S. Govt. Printing Office), 827-842.

Bryant, W.R., Bennett, R.H., and Katherman, C.E., 1981. Shear strength, consolidation, porosity, and permeability of oceanic sediments. In Emiliani, C. (Ed.), The Sea (Vol. 7): The Oceanic Lithosphere: New York (Wiley), 1555-1616.

Carson, B., 1977. Tectonically induced deformation of deep-sea sediments off Washington and northern Oregon: mechanical consolidation. Mar. Geol., 24:289-307.

* Abbreviations for names of organizations and publication titles in ODP reference lists follow the style given in Chemical Abstracts Service Source Index (published by American Chemical Society). 
Carson, B., and Berglund, P.L., 1986. Sediment deformation and dewatering under horizontal compression: experimental results. In Moore, J.C. (Ed.), Structural Fabric in Deep Sea Drilling Project Cores From Forearcs. Mem.-Geol. Soc. Am., 166:135-150.

Dahlen, F.A., Suppe, J., and Davis, D.M., 1984. Mechanics of fold and thrust belts and accretionary wedges: cohesive Coulomb theory. J. Geophys. Res., 89:10087-10101.

Davis, D.M., Suppe, J., and Dahlen, F.A., 1983. Mechanics of fold-and-thrust belts and accretionary wedges. J. Geophys. Res., 88:1153-1172.

Davis, D.M., and von Huene, R., 1987. Inferences on sediment strength and fault friction from structures at the Aleutian Trench. Geology, 15:517-522.

Fisher, A.T., and Hounslow, M.W., 1990. Transient fluid flow through the toe of the Barbados accretionary complex: constraints from Ocean Drilling Program Leg 110 heat flow studies and simple models. J. Geophys. Res., 95:8845-8858.

Fowler, S.R., White, R.S., and Louden, K.E., 1985. Sediment dewatering in the Makran accretionary prism. Earth Planet. Sci. Lett., 75:427-438.

Gretner, P.E., 1976. Pore pressures: fundamentals, general ramifications, and implications for structural geology. AAPG Continuing Educ. Course Note, Ser. 4.

Hubbert, R., and Rubey, J., 1959. Role of fluid pressures in mechanics of overthrust faulting: Part 1. Geol. Soc. Am. Bull., 70:115-166.

Johns, M.W., 1986. Consolidation and permeability characteristic of Japan Trench and Nankai Trough sediments from DSDP Leg 87, Sites 582, 583, and 584. In Kagami, H., Karig, D.E., Coulbourn, W.T., et al., Init. Repts. DSDP, 87: Washington (U.S. Govt. Printing Office), 843-849.

Karato, S., and Becker, K., 1983. Porosity and hydraulic properties of sediments from the Galapagos Spreading Center and their relation to hydrothermal circulation in the oceanic crust. J. Geophys. Res., 88:1009-1017.

Karig, D.E., 1985. The framework of deformation in the Nankai Trough. In Kagami, H., Karig, D.E., Coulbourn, W.T., et al., Init. Repts. DSDP, 87: Washington (U.S. Govt. Printing Office) $927-940$.

, 1986. Physical properties and mechanical state of accreted sediments in the Nankai Trough, Southwest Japan Arc. In Moore, J.C. (Ed.), Structural Fabrics in Deep Sea Drilling Project Cores from Forearcs. Mem.-Geol. Soc. Am., 166:117-133.

Lambe, T.W., and Whitman, R.V., 1969. Soil Mechanics: New York (Wiley).

Moore, G.F., Karig, D.E., Shipley, T.H., Taira, A., Stoffa, L., and Wood, W.T., 1991. Structural framework of the ODP Leg 131 area, Nankai Trough. In Taira, A., Hill, I., Firth, J.V., et al., Proc. ODP, Init. Repts., 131: College Station, TX (Ocean Drilling Program), 15-20.

Moore, J.C., and Biju-Duval, B., 1982. Offscraping and underthrusting of sediment at the deformation front of the Barbados Ridge: Deep Sea Drilling Project Leg 78A. Geol. Soc. Am. Bull., 93:1065-1077.

Moore, J.C., Mascle, A., Taylor, E., Andreieff, P., Alvarez, F., Barnes, R., Beck, C., Behrmann, J., Blanc, G., Brown, K., Clark, M., Dolan, J., Fisher, A., Gieskes, J., Hounslow, M., McLellan, P., Moran, K., Ogawa, Y., Sakai, T., Schoonmaker, J., Vrolijk, P., Wilkens, R., and Williams, C., 1988. Tectonics and hydrogeology of the northern Barbados Ridge: results from Ocean Drilling Program Leg 110. Geol. Soc. Am. Bull., 100:1578-1593.

Ngokwey, K., 1984. Numerical modeling of sediment deformation linked to subduction: mechanical model and comparison with Barbados ridge complex. In Biju-Duval, B., Moore, J.C., et al., Init. Repts. DSDP, 78: Washington (U.S. Govt. Printing Office), 559-568.

Olsen, H.W., Nichols, R.W., and Rice, T.C., 1985. Low gradient permeability measurements in a triaxial system. Geotechnique, 35:145-157.

Rubey, J., and Hubbert, R., 1956. Role of fluid pressures in mechanics of overthrust faulting: Part 2. Geol. Soc. Am. Bull., 70:115-166.

Schultheiss, P.J., McPhail, S.D., Packwood, A.R., and Hart, B., 1985. An instrument to measure differential pore pressures in deep sea sediments: pop up pore pressure instrument (PUPPI). Inst. of Oceanogr. Sci. Rep., 202.
Screaton, E.J., Wuthrich, D.R., and Dreiss, S.J., 1990. Fluid flow within the Barbados Ridge complex, Part I: dewatering within the toe of the prism. In Moore, J.C., Mascle, A., et al., Proc. ODP, Sci. Results, 110: College Station, TX (Ocean Drilling Program), 321-329.

Shephard, L.E., and Bryant, W.R., 1983. Geotechnical properties of lower trench inner-slope sediments. Tectonophysics, 99:279-312.

Shi, Y., and Wang, C.-Y., 1985. High pore pressure generation in sediments in front of the Barbados Ridge Complex. Geophys. Res. Lett., 12:773-776.

, 1987. Two dimensional modelling of the P-T-t paths of regional metamorphism in simple overthrust terrains. Geology, 15:1048-1051.

Silva, A., Hetherman, J.R., and Calnan, D.I., 1981. Low gradient permeability testing of fine-grained marine sediments. In Zimmie, T.F., and Riggs, C.O. (Eds.), Permeability and Groundwater Transport. ASTM Spec. Tech. Publ., 746:121-136.

Stride, A.H., Beldeson, R.H., and Kenyon, N.H., 1982. Structural grain, mud volcanoes and other features on the Barbados Ridge Complex revealed by GLORIA long range side-scan sonar. Mar. Geol., 49:187-196.

Taira, A., Hill, I., Firth, J., Berner, U., Brückmann, W., Byrne, T., Chabernaud, T., Fisher, A., Foucher, J.-P., Gamo, T., Gieskes, J., Hyndman, R., Karig, D., Kastner, M., Kato, Y., Lallement, S., Lu, R., Maltman, A., Moore, G., Moran, K., Olaffson, G., Owens, W., Pickering, K., Siena, F., Taylor, E., Underwood, M., Wilkinson, C., Yamano, M., and Zhang, J., 1992. Sediment deformation and hydrogeology of the Nankai accretionary prism: synthesis of shipboard results of ODP Leg 131. Earth Planet. Sci. Lett., 109:431-450.

Taira, A., Hill, I., Firth, J.V., et al., 1991. Proc. ODP, Init. Repts., 131: College Station, TX (Ocean Drilling Program).

Taylor, E., 1992. Oceanic sedimentation and geotechnical stratigraphy: hemipelagic carbonates and red clays. In Geyer, R.A. (Ed.), Handbook of Geophysical Exploration: Boca Raton, FL (CRC Press), 403-458.

Taylor, E., and Bryant, W.R., 1985. Geotechnical properties of sediments from the Middle America Trench and slope. In von Huene, R., Aubouin, J., et al., Init. Repts. DSDP, 84: Washington (U.S. Govt. Printing Office), 745-766.

Taylor, E., and Leonard, J., 1990. Sediment consolidation and permeability at the Barbados forearc. In Moore, J.C., Mascle, A., et al., Proc. ODP, Sci. Results, 110: College Station, TX (Ocean Drilling Program), 289-308.

Terzaghi, K., 1943. Theoretical Soil Mechanics: New York (Wiley).

Trabant, P.K., Bryant, W.R., and Bouma, A.H., 1975. Consolidation characteristics of sediments from Leg 31 of the Deep Sea Drilling Project. In Karig, D.E., Ingle, J.C., Jr., et al., Init. Repts. DSDP, 31: Washington (U.S. Govt. Printing Office), 569-572.

von Huene, R., and Lee, H.J., 1982. The possible significance of pore fluid pressures in subduction zones. In Watkins, J.S., and Drake, C.L. (Eds.), Studies in Continental Margin Geology. AAPG Mem., 34:781-789.

Westbrook, G.K., and Smith, M.J., 1983. Long décollements and mud volcanoes: evidence from the Barbados Ridge Complex for the role of high pore-fluid pressure in the development of an accretionary complex. Geology, 11:279-283.

Wuthrich, D.R., Screaton, E.J., and Dreiss, S.J., 1990. Fluid flow within the Barbados Ridge complex, Part II: permeability estimates and numerical simulations of flow velocities and pore pressures. In Moore, J.C., Mascle, A., et al., Proc. ODP, Sci. Results, 110: College Station, TX (Ocean Drilling Program), 331-341.

Zimmie, T.F., and Riggs, C.O. (Eds.), 1981. Permeability and Groundwater Contaminant Transport, ASTM Spec. Tech. Publ., 746.

Date of initial receipt: 11 February 1992

Date of acceptance: 13 October 1992

Ms 131SR-131 
E. TAYLOR, A. FISHER

A

Permeability anisotropy
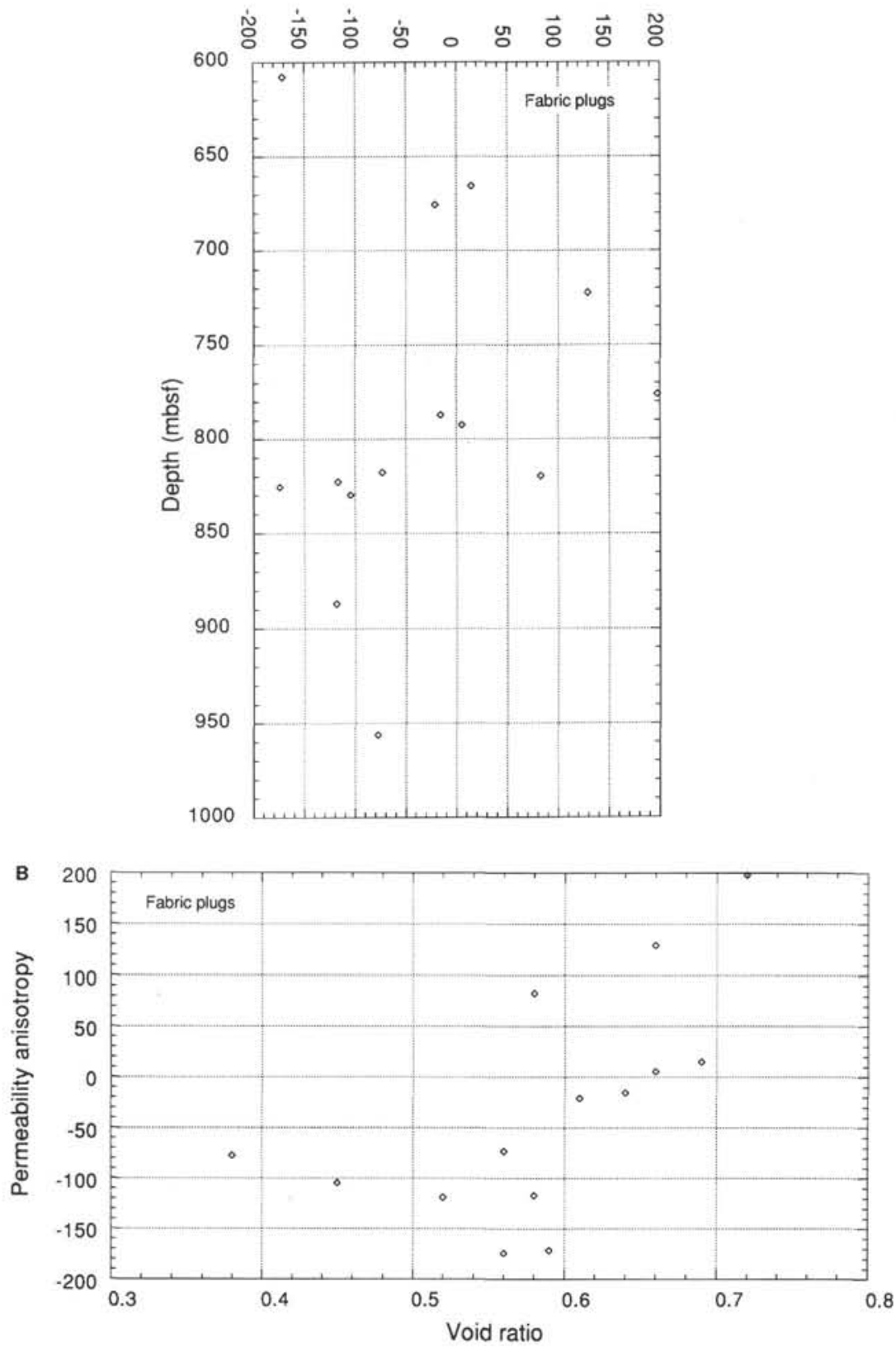

Figure 7. Permeability anisotropy (as defined in the text) vs. (A) depth and (B) void ratio. 


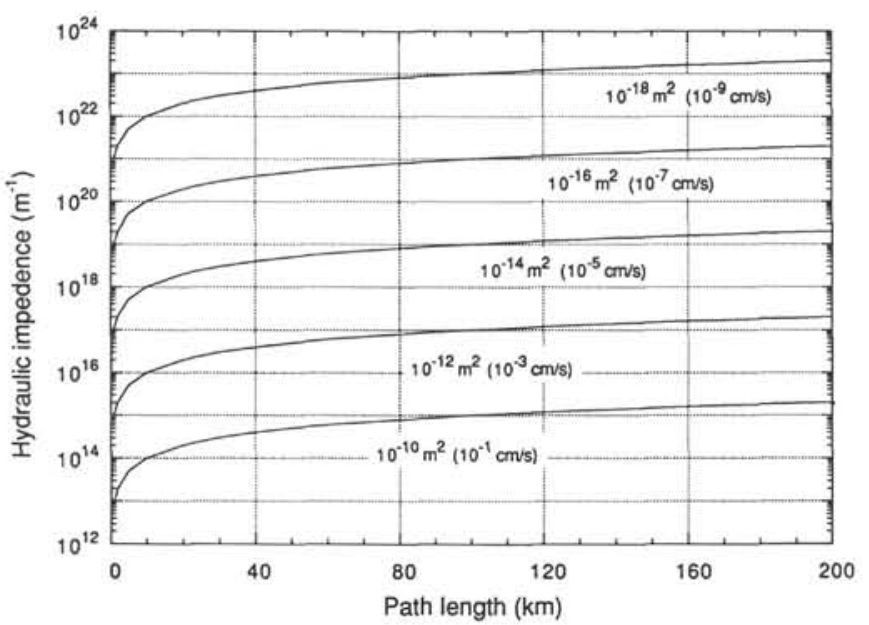

Figure 8. Type curves of hydraulic impedance as a function of path length for different constant permeabilities. 